Supplement of

\title{
Atmospheric oxidation capacity and ozone pollution mechanism in a coastal city of southeastern China: analysis of a typical photochemical episode by an observation-based model
}

Taotao Liu et al.

Correspondence to: Jinsheng Chen (jschen@iue.ac.cn) and Likun Xue (xuelikun@sdu.edu.cn)

The copyright of individual parts of the supplement might differ from the article licence. 
Figure S1. The concentrations of monthly and annual MDA8h $\mathrm{O}_{3}$ in Xiamen from 2016 to 2020.

Figure S2. $72 \mathrm{~h}$ back trajectories were calculated at $100 \mathrm{~m}$ altitude during 20-29 Sep. 2019.

Figure S3. Daytime (06:00-18:00 LT) variations of the simulated concentration, production, and loss rate of (a)OH, (b) $\mathrm{HO}_{2}$, and (c) $\mathrm{RO}_{2}$ in Xiamen.

Figure S4. Synoptic situations of surface wind field from 20 to 29 Sep. 2019. Arrows in the figure represent the surface wind speed and direction. The blue square is the study site.

30 Table S1. Comparison of NO, $\mathrm{NO}_{2}$ and total VOCs levels in cities between China and other countries.

32 Table S2. Dry deposition velocity $\left(\mathrm{cm} \mathrm{s}^{-1}\right)$ for chemical species.

Table S3. Estimated degree of freedom (Edf), degree of reference (Ref. df), P-value, $\mathrm{F}$-value, deviance explained (\%), adjusted $\mathrm{R}^{2}$ for the smoothed variables (including 


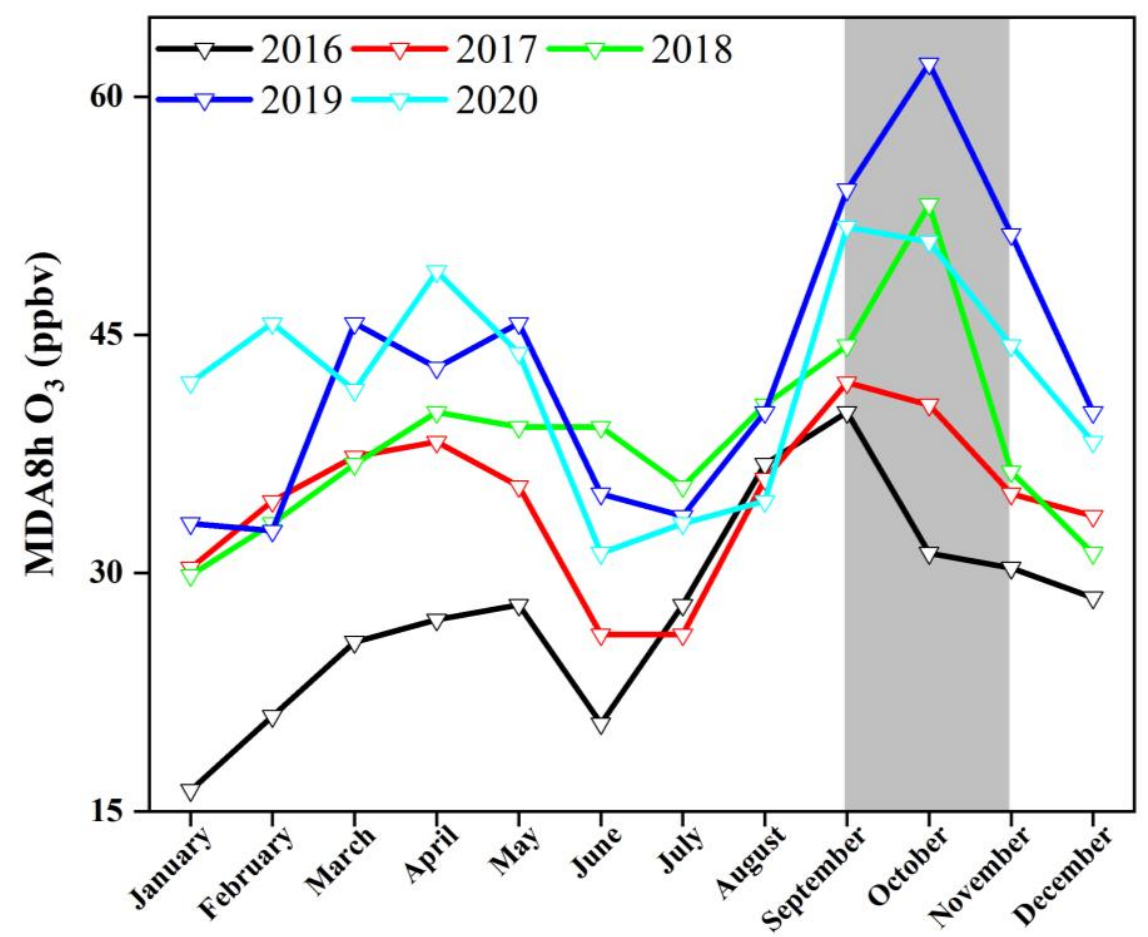

Figure S1. The concentrations of monthly and annual MDA8h $O_{3}$ in Xiamen from 2016 to 43 2020.

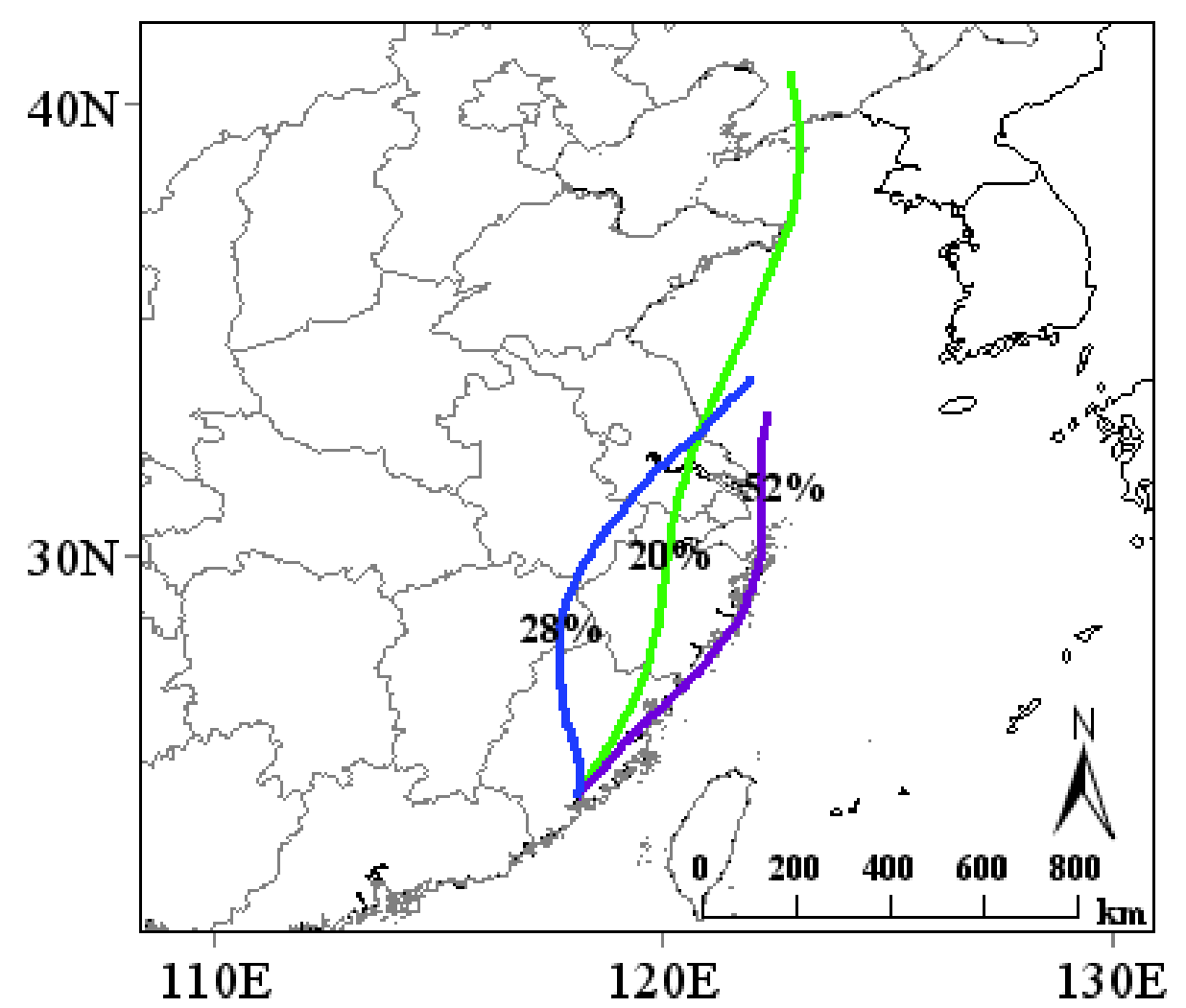



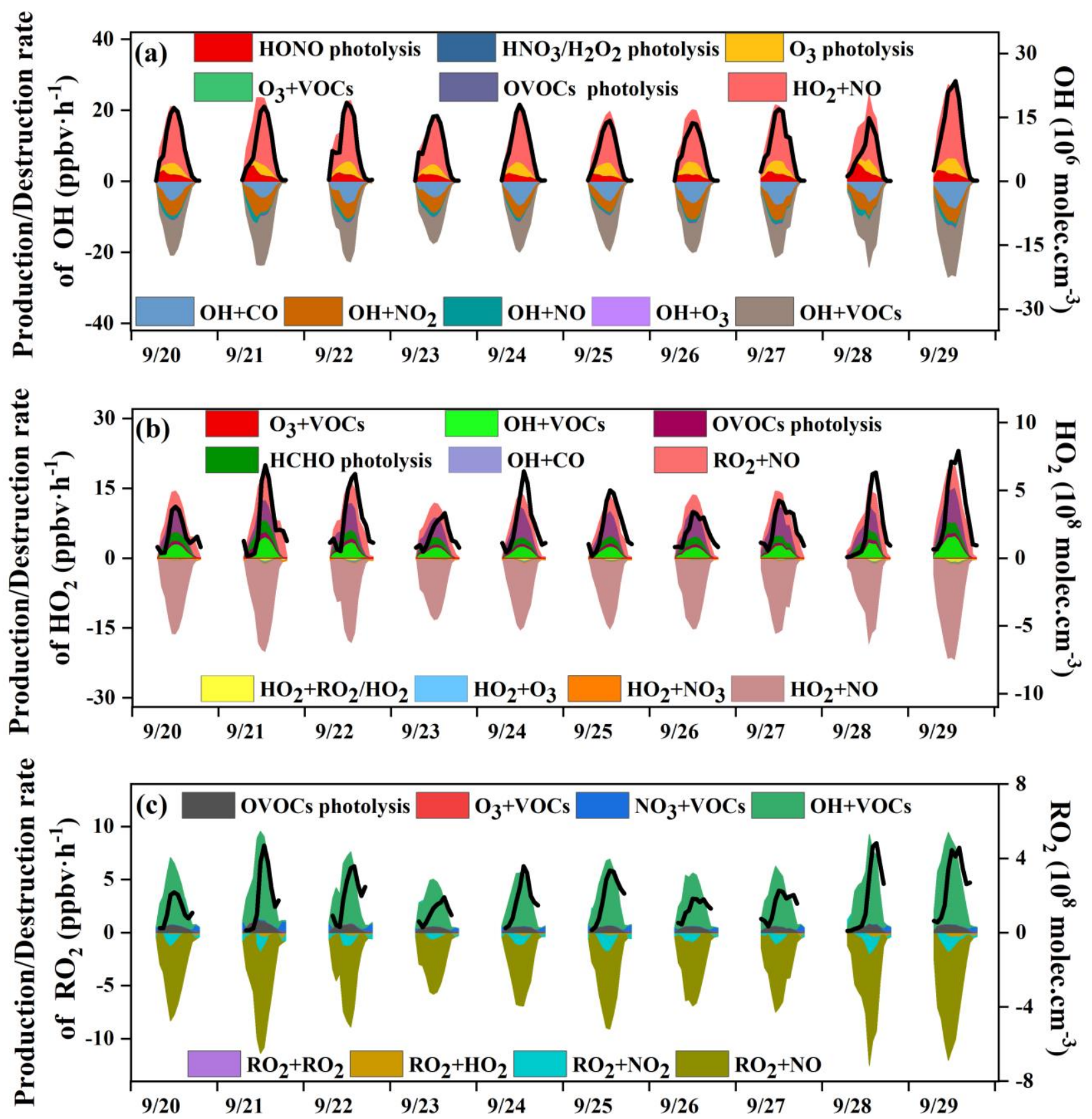

Figure S3. Daytime (06:00-18:00 LT) variations of the simulated concentration, production, 52 and loss rate of (a)OH, (b) $\mathrm{HO}_{2}$, and (c) $\mathrm{RO}_{2}$ in Xiamen. 


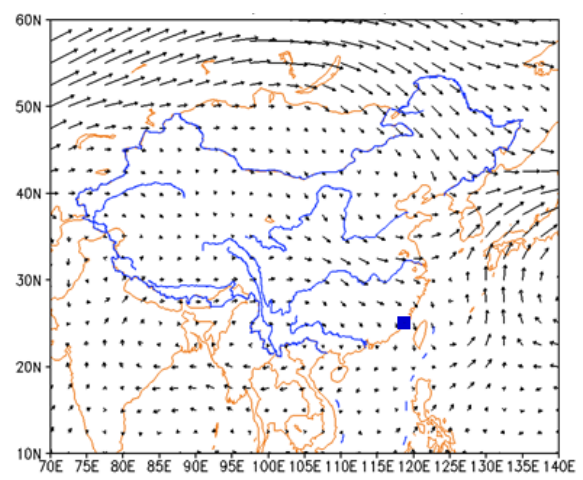

(a) $500 \mathrm{hPa} 20-22 \mathrm{sep}$

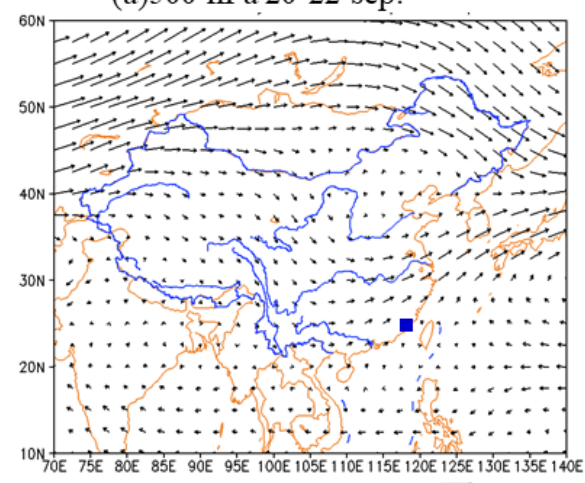

(d) $500 \mathrm{hPa} 23-27 \mathrm{sep}$.

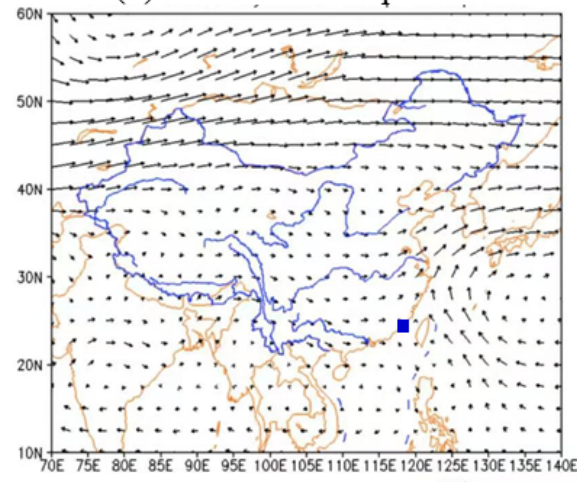

(g) $500 \mathrm{hPa} 28-29 \mathrm{sep}$

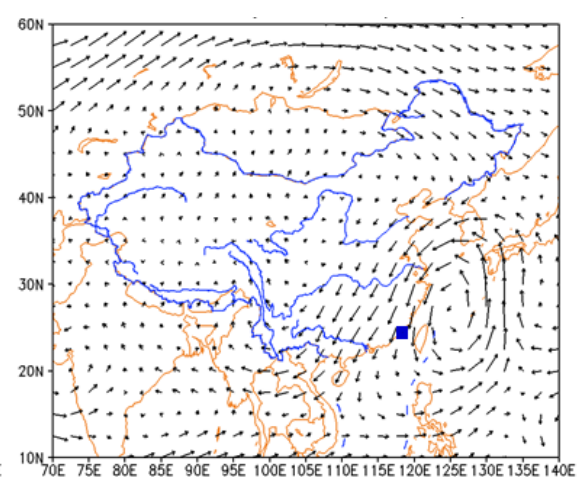

(b) $850 \mathrm{hPa}, 20-22 \mathrm{sep}$.

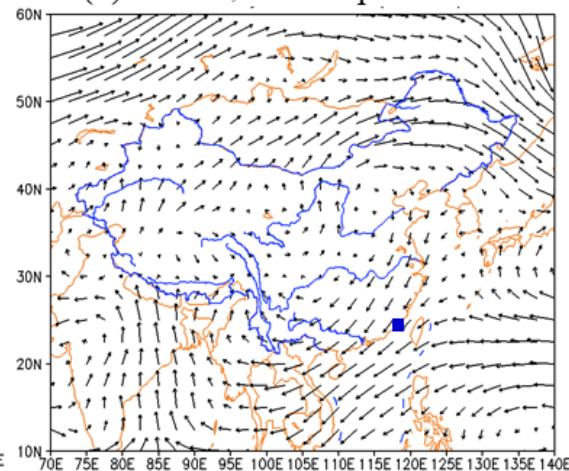

(e) $850 \mathrm{hPa}, 23-27 \mathrm{sep}$.

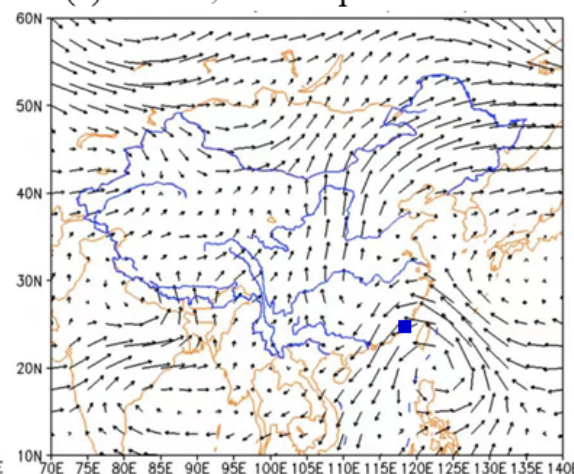

(h) $850 \mathrm{hPa}, 28-29 \mathrm{sep}$.

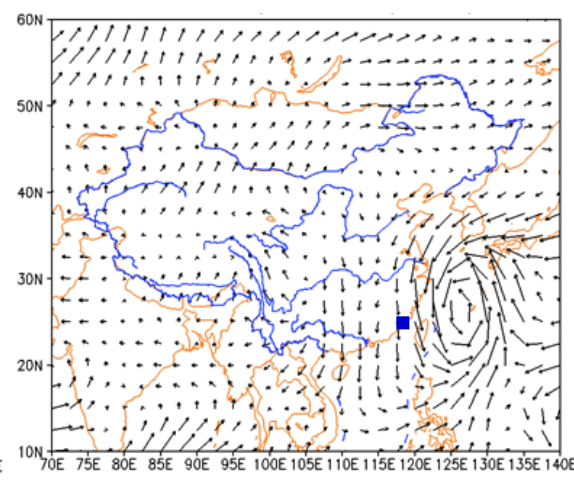

(c) $1000 \mathrm{hPa}, 20-22 \mathrm{sep}$.

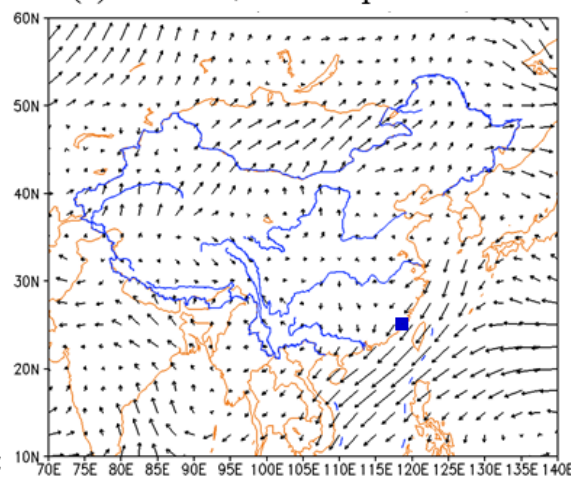

(f) $1000 \mathrm{hPa}, 23-27 \mathrm{sep}$

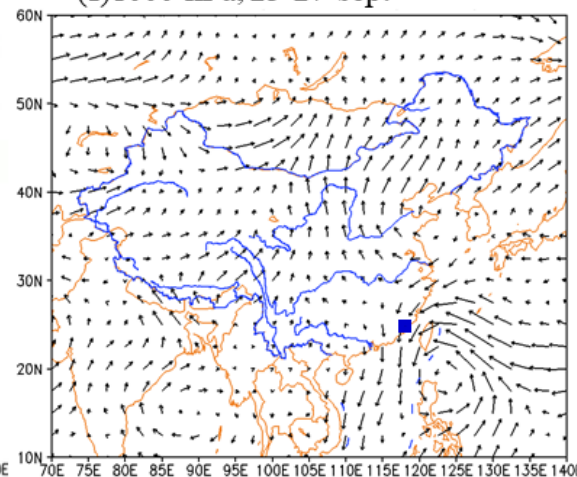

(i) $1000 \mathrm{hPa}, 28-29 \mathrm{sep}$.

Figure S4. Synoptic situations of surface wind field from 20 to 29 Sep. 2019. Arrows in the figure represent the surface wind speed and direction. The blue square is the study site.

Table S1. Comparison of NO, $\mathrm{NO}_{2}$ and total VOCs levels in cities between China and other countries (Units: ppbv).

\begin{tabular}{ccccccc} 
Location & $\mathrm{NO}_{2}$ & $\mathrm{NO}$ & VOCs & Site category & Observation periods & Reference \\
\hline Xiamen & 15.4 & 1.4 & 17.2 & Urban & Sep. 2019 (episode) & This study \\
Beijing & 16.8 & 2.1 & 44.2 & Urban & & Liu et al., 2021b \\
Wuhan & 17.5 & 3.2 & 30.2 & Urban & Summer 2018 (episode) & Liu et al., 2021b \\
Lanzhou & 15.8 & 2.9 & 45.3 & Urban & & Liu et al., 2021b \\
Shanghai & 14.2 & 3.38 & 25.3 & Urban & Jun. 2019 (episode) & Zhu et al., 2020 \\
Chengdu & 39.0 & 3.6 & 36.0 & Urban & Jul. 2017 (episode) & Yang et al., 2020 \\
Los Angeles & - & - & 41.3 & Urban & May.-Jun. 2010 & Warneke et al., 2012 \\
London & - & - & 22.1 & Urban & $1998-2008$ & Von Schneidemesser et al., 2010 \\
Tokyo & - & - & 43.4 & Urban & 2003-2005 & Hoshi et al., 2008
\end{tabular}




$\begin{array}{ccccccc}\text { Beijing } & 11.5 & 4.8 & 28.1 & \text { Suburban } & \text { Aug. 2018 } & \text { Yang et al., 2021 } \\ \text { Hong Kong } & 25.0 & 14.0 & 26.9 & \text { Suburban } & \text { Aug. to Nov. 2013 } & \text { Wang et al., 2018 } \\ \text { Chengdu } & 11.4 & 8.0 & 28.0 & \text { Suburban } & \text { Summer 2019 } & \text { Yang et al., 2021a } \\ \text { Qingdao } & 16.7 & 1.6 & 7.6 & \text { Rural } & \text { Oct.-Nov. 2019 } & \text { Liu et al., 2021a } \\ \text { Pearl River Delta } & 39.9 & 4.2 & 38.0 & \text { Rural } & \text { Octo.-Nov. 2014 } & \text { He et al., 2019 } \\ \text { Hong Kong } & 12.2 & 1.9 & 10.9 & \text { Regional background } & \text { Aug.-Dec. 2012 } & \text { Li et al., 2018 } \\ \text { Mt. Wuyi } & - & - & 4.7 & \text { Background } & \text { Dec. 2016 } & \text { Hong et al., 2019 } \\ \text { Mt. Tai } & - & - & 8.8 & \text { Background } & \text { Jun. 2006 } & \text { Suthawaree et al., 20 }\end{array}$

$\begin{array}{lllllll}\text { Mt. Waliguan } & - & - & 2.6 & \text { Remote region } & \text { Jul.-Aug. } 2003\end{array}$

61 Note: "-" means that the data was not mentioned in the relevant studies.

62

63 Table S2. Dry deposition velocity $\left(\mathrm{cm} \mathrm{s}^{-1}\right)$ for chemical species (Zhang et al., 2003).

\begin{tabular}{|c|c|c|}
\hline Symbol & Name & dry deposition velocity \\
\hline $\mathrm{O}_{3}$ & Ozone & 0.6 \\
\hline $\mathrm{NO}_{2}$ & Nitrogen dioxide & 0.6 \\
\hline HONO & Nitrous acid & 1.9 \\
\hline $\mathrm{HNO}_{3}$ & Nitric acid & 4.7 \\
\hline $\mathrm{HNO}_{4}$ & Pernitric acid & 3.3 \\
\hline $\mathrm{NH}_{3}$ & Ammonia & 1 \\
\hline $\mathrm{SO}_{2}$ & Sulphur dioxide & 0.8 \\
\hline $\mathrm{H}_{2} \mathrm{SO}_{4}$ & Sulphuric acid & 1.1 \\
\hline $\mathrm{H}_{2} \mathrm{O}_{2}$ & Hydrogen peroxide & 1.2 \\
\hline PAN & Peroxyacetylnitrate & 0.4 \\
\hline PPN & Peroxypropylnitrate & 0.4 \\
\hline APAN & Aromatic acylnitrate & 0.5 \\
\hline MPAN & Peroxymethacrylic nitric anhydride & 0.3 \\
\hline $\mathrm{HCHO}$ & Formaldehyde & 0.9 \\
\hline $\mathrm{MCHO}$ & Acetaldehyde & 0.2 \\
\hline PALD & C3 Carbonyls & 0.2 \\
\hline $\mathrm{C} 4 \mathrm{~A}$ & C4-C5 Carbonyls & 0.2 \\
\hline C7A & C6-C8 Carbonyls & 0.2 \\
\hline $\mathrm{ACHO}$ & Aromatic carbonyls & 0.2 \\
\hline MVK & Methyl-vinyl-ketone & 0.2 \\
\hline MACR & Methacrolein & 0.2 \\
\hline MGLY & Methylgloxal & 0.2 \\
\hline $\mathrm{MOH}$ & Methyl alcohol & 0.7 \\
\hline ETOH & Ethyl alcohol & 0.6 \\
\hline $\mathrm{POH}$ & C3 alcohol & 0.5 \\
\hline CRES & Cresol & 0.2 \\
\hline FORM & Formic acid & 1.4 \\
\hline $\mathrm{ACAC}$ & Acetic acid & 1.1 \\
\hline $\mathrm{ROOH}$ & Organic peroxides & 0.6 \\
\hline ONIT & Organic nitrates & 0.4 \\
\hline INIT & Isoprene nitrate & 0.3 \\
\hline
\end{tabular}


Table S3. Estimated degree of freedom (Edf), degree of reference (Ref. df), P-value, F-value, 68 deviance explained (\%), adjusted $\mathbf{R}^{2}$ for the smoothed variables (including $\mathrm{UV}, \mathrm{T}, \mathrm{RH}, \mathrm{P}$, and 69 WS) in the GAM model.

\begin{tabular}{ccccccc}
\hline Smoothed variables & ${ }^{\mathrm{a}}$ Edf & ${ }^{\mathrm{a}}$ Ref.df & ${ }^{\mathrm{b}} \mathrm{F}$ & ${ }^{\mathrm{c} P}$-value & ${ }^{\mathrm{d}}$ Adjust $\mathrm{R}^{2}$ & e Deviance explained (\%) \\
\hline $\mathrm{UV}\left(\mathrm{W} \cdot \mathrm{m}^{-2}\right)$ & 3.1 & 3.8 & 3.0 & 0.0 & 0.0 & 5.4 \\
$\mathrm{~T}\left({ }^{\circ} \mathrm{C}\right)$ & 5.3 & 6.5 & 10.9 & 0.0 & 0.2 & 24.1 \\
$\mathrm{RH}(\%)$ & 2.9 & 3.6 & 40.1 & 0.0 & 0.4 & 38.9 \\
$\mathrm{WS}\left(\mathrm{m} \cdot \mathrm{s}^{-1}\right)$ & 2.9 & 3.6 & 26.9 & 0.0 & 0.3 & 29.3 \\
$\mathrm{P}(\mathrm{hPa})$ & 6.9 & 8.0 & 3.9 & 0.0 & 0.1 & 13.4 \\
\hline
\end{tabular}

Note: ${ }^{a}$ The degree of freedom (edf, ref.df) of the explanatory variable is 1 , indicating the linear relationships between the explanatory variable and the response variable, and a non-linear relationship is shown when the degree $>1 ;{ }^{\mathrm{b}}$ a high F-value indicates the great importance of the influencing factor; ${ }^{\mathrm{c}}$ the $\mathrm{P}$-value is used to judge the significance of the model result; ${ }^{\mathrm{d}}$ the adjusted $\mathrm{R}^{2}$ is the value of the regression square ranging from 0 to 1 ; ${ }^{\mathrm{e}}$ the deviance explained represents the fitting effect.

\section{References:}

Liu, Z., Wang, Y., Hu, B., Lu, K., Tang, G., Ji, D., Yang, X., Gao, W., Xie, Y., Liu, J., Yao, D., Yang, Y., and Zhang, Y.: Elucidating the quantitative characterization of atmospheric oxidation capacity in Beijing, China, Sci Total Environ, 771, 145306, 10.1016/j.scitotenv.2021.145306, 2021a.

Liu, X., Guo, H., Zeng, L., Lyu, X., Wang, Y., Zeren, Y., Yang, J., Zhang, L., Zhao, S., Li, J., and Zhang, G.: Photochemical ozone pollution in five Chinese megacities in summer 2018, Sci Total Environ, 149603, 10.1016/j.scitotenv.2021.149603, $2021 \mathrm{~b}$.

Yang, X., Wu, K., Wang, H., Liu, Y., Gu, S., Lu, Y., Zhang, X., Hu, Y., Ou, Y., Wang, S., and Wang, Z.: Summertime ozone pollution in Sichuan Basin, China: Meteorological conditions, sources and process analysis, Atmos. Environ., 226, 117392, 10.1016/j.atmosenv.2020.117392, 2020.

Warneke, C., Gouw, J.A., Holloway, J.S., Peischl, J., Ryerson, T.B., Atlas, E., Blake, D., Trainer, M., Parrish, D.D.: Multiyear trends in volatile organic compounds in Los Angeles, California: five decades of decreasing emissions. J. Geophys. Res.-Atmos. 117 (D21). http://dx.doi.org/10.1029/2012JD017899, 2012.

Von Schneidemesser, E., Monks, P.S., Plass-Duelmer, C.: Global comparison of VOC and CO observations in urban areas. Atmos. Environ. 44 (39), 5053-5064, 2010.

Hoshi, J.Y., Amano, S., Sasaki, Y., Korenaga, T.: Investigation and estimation of emission sources of 54 volatile organic compounds in ambient air in Tokyo. Atmos. 
Environ. 42 (10), 2383-2393, 2008.

Wang, H., Lyu, X., Guo, H., Wang, Y., Zou, S., Ling, Z., Wang, X., Jiang, F., Zeren, Y., Pan, W., Huang, X., and Shen, J.: Ozone pollution around a coastal region of South China Sea: interaction between marine and continental air, Atmos. Chem. Phys., 18, 4277-4295, 10.5194/acp-18-4277-2018, 2018.

Yang, Y., Wang, Y., Huang, W., Yao, D., Zhao, S., Wang, Y., Ji, D., Zhang, R., and Wang, Y.: Parameterized atmospheric oxidation capacity and speciated $\mathrm{OH}$ reactivity over a suburban site in the North China Plain: A comparative study between summer and winter, Sci Total Environ, 773, 145264, 10.1016/j.scitotenv.2021.145264, 2021.

Yang, X., Lu, K., Ma, X., Liu, Y., Wang, H., Hu, R., Li, X., Lou, S., Chen, S., Dong, H., Wang, F., Wang, Y., Zhang, G., Li, S., Yang, S., Yang, Y., Kuang, C., Tan, Z., Chen, X., Qiu, P., Zeng, L., Xie, P., and Zhang, Y.: Observations and modeling of OH and HO2 radicals in Chengdu, China in summer 2019, Sci Total Environ, 772, 144829,2021a 10.1016/j.scitotenv.2020.144829, 2021a.

Tiwari, V., Hanai, Y., Masunaga, S., 2010. Ambient levels of volatile organic compounds in the vicinity of petrochemical industrial area of Yokohama, Japan. Air Qual. Atmos. Health 3 (2), 65-75.

He, Z., Wang, X., Ling, Z., Zhao, J., Guo, H., Shao, M., and Wang, Z.: Contributions of different anthropogenic volatile organic compound sources to ozone formation at a receptor site in the Pearl River Delta region and its policy implications, Atmospheric Chemistry and Physics, 19, 8801-8816, 10.5194/acp-19-8801-2019, 2019.

Li, Z., Xue, L., Yang, X., Zha, Q., Tham, Y. J., Yan, C., Louie, P. K. K., Luk, C. W. Y., Wang, T., and Wang, W.: Oxidizing capacity of the rural atmosphere in Hong Kong, Southern China, Sci Total Environ, 612, 1114-1122, 10.1016/j.scitotenv.2017.08.310, 2018.

Suthawaree, J., Kato, S., Okuzawa, K., Kanaya, Y., Pochanart, P., Akimoto, H., Wang, Z., and Kajii, Y.: Measurements of volatile organic compounds in the middle of Central East China during Mount Tai Experiment 2006 (MTX2006): observation of regional background and impact of biomass burning, Atmos. Chem. Phys., 10, 1269-1285, doi:10.5194/acp-10-1269-2010, 2010.

Xue, L. K. , Wang, T. , Guo, H. , Blake, D. R. , Tang, J. , \& Zhang, X. C. , et al.: Sources and photochemistry of volatile organic compounds in the remote atmosphere of western China: results from the Mt. Waliguan Observator, Atmos. Chem. Phys., 10.5194/acp13-8551-2013, 2013.

Hong, Z., Li, M., Wang, H., Xu, L., Hong, Y., Chen, J., Chen, J., Zhang, H., Zhang, Y., $\mathrm{Wu}, \mathrm{X}$., Hu, B., and Li, M.: Characteristics of atmospheric volatile organic compounds (VOCs) at a mountainous forest site and two urban sites in the southeast of China, Sci Total Environ, 10.1016/j.scitotenv.2018.12.132, 2019.

Zhu, J., Wang, S., Wang, H., Jing, S., Lou, S., Saiz-Lopez, A., and Zhou, B.: 
138 Observationally constrained modeling of atmospheric oxidation capacity and 139 photochemical reactivity in Shanghai, China, Atmos. Chem. Phys., 20, 1217-1232, $140 \quad 10.5194 /$ acp-20-1217-2020, 2020.

141 